\title{
Astemizole protects against human umbilical vein endothelial cell injury induced by hydrogen peroxide via the $\mathbf{p 5 3}$ signaling pathway
}

\author{
JIA-NAN TIAN, XIAO-DONG SHI, XIAO-KUN WANG, SHUANG WANG, JING-XUE XU and CHUN-XIAO YANG \\ Department of Neurology, The Second Affiliated Hospital of Harbin Medical University, \\ Harbin, Heilongjiang 150081, P.R. China
}

Received February 9, 2016; Accepted January 30, 2017

DOI: $10.3892 / \mathrm{mmr} .2017 .6497$

\begin{abstract}
Astemizole has gained attention as an antineoplastic drug that targets important ion channels. The present study aimed to investigate the protective effects of astemizole against hydrogen peroxide $\left(\mathrm{H}_{2} \mathrm{O}_{2}\right)$-induced oxidative damage to human umbilical vein endothelial cells (HUVECs). HUVECs were pretreated with astemizole $(0.5$ and $1 \mu \mathrm{M})$ for $12 \mathrm{~h}$, then exposed to $\mathrm{H}_{2} \mathrm{O}_{2}(200 \mu \mathrm{M})$ for $12 \mathrm{~h}$. Cell viability was measured using the MTT assay. The levels of malondialdehyde (MDA), superoxide dismutase (SOD), glutathione peroxidase (GSH-Px), reactive oxygen species (ROS) and apoptotic percentage were determined. Additionally, the protein expression of p53, p21 $1^{\mathrm{Cip} 1 / \text { Waf1 }}$ and $\mathrm{p} 16^{\mathrm{INK} 4 \mathrm{a}}$ was measured by western blot analysis The results demonstrated that astemizole $(0.5-1 \mu \mathrm{M})$ was able to significantly restore the viability of HUVECs under oxidative stress and scavenge intracellular ROS induced by $\mathrm{H}_{2} \mathrm{O}_{2}$. Astemizole also suppressed the production of lipid peroxides, such as MDA, and restored the activities of endogenous antioxidants, including SOD and GSH-Px, indicating that cell apoptosis may be inhibited. In addition, astemizole significantly increased p53, p21 $1^{\mathrm{Cip} / \mathrm{Wafl}}$ and p16 $6^{\mathrm{INK} 4 \mathrm{a}}$ protein expression. In conclusion, astemizole effectively protected endothelial cells against oxidative stress induced by $\mathrm{H}_{2} \mathrm{O}_{2}$, a function that may involve ROS/p53/p21 Cip1/Waf1/ $^{2}$ p16 $6^{\text {INK4a }}$ signaling pathways. The present study therefore served as a preliminary investigation into the ROS-protective effects of astemizole, and may pave the way for future studies into the development of this compound as a novel therapy for atherosclerosis.
\end{abstract}

Correspondence to: Dr Chun-Xiao Yang, Department of Neurology, The Second Affiliated Hospital of Harbin Medical University, 148 Bao Jian Road, Harbin, Heilongjiang 150081, P.R. China

E-mail: yangchunxiao72@163.com

Key words: astemizole, human umbilical vein endothelial cells, hydrogen peroxide, reactive oxygen species, p53

\section{Introduction}

Astemizole, used for many years as an H1-histamine receptor antagonist, is a long-acting, non-sedating, second-generation anti-histamine, which is currently used in certain countries to treat allergy symptoms (1). However, astemizole has gained attention as an antineoplastic drug (2) as it targets important ion channels involved in cancer progression, such as potassium voltage-gated channel subfamily $\mathrm{H}$ member 1 in breast cancer (3). Compared with calcitriol, the antineoplastic effects of astemizole involve different mechanisms of action, including antagonizing H1-histamine receptors (2), reducing P450-aromatase expression (4) and inhibiting the release of inflammatory mediators (5), and this may further improve therapeutic efficacy when these drugs are jointly administered. The reported therapeutic and toxic serum levels of astemizole are $0.05 \mathrm{mg} / \mathrm{ml}(0.10 \mathrm{mM})$ and $14 \mathrm{mg} / \mathrm{m}(30.5 \mathrm{mM})$, respectively (6). Nishimoto et al (6) previously examined the effects of astemizole, a non-sedating antihistamine, on ventricular activation and RT intervals in a canine myocardial infarction model and Romero et al (7) investigated the impact of potassium voltage-gated channel subfamily $\mathrm{H}$ member 2 channel kinetic abnormalities on channel block and susceptibility to acquired long QT syndrome. Therefore, the present study aimed to investigate the effect of astemizole in cardiovascular diseases (CVDs).

CVDs are the leading causes of death and disability among aged people worldwide (8), and hypertension and arteriosclerosis have important roles in CVD. Functional impairment of vascular endothelial cells is involved in the establishment of hypertension and arteriosclerosis (9), therefore, the maintenance of vascular endothelial function is important to prevent hypertension and arteriosclerosis (10). A number of diseases involve the generation of reactive oxygen species (ROS) by vascular endothelial cells, including atherosclerosis, hypercholesteremia and disseminated intravascular coagulation $(11,12)$. Increased levels of ROS in vascular lesions have been demonstrated to have detrimental effects on a number of processes, resulting in the peroxidation of membrane lipids, endothelium-derived enzyme inactivation and the occurrence of apoptosis (13). As one of the most common forms ROS, hydrogen peroxide $\left(\mathrm{H}_{2} \mathrm{O}_{2}\right)$ crosses the 
plasma membrane easily and produces a highly reactive radical, $\ddot{\mathrm{Y} O H}$, that damages cells and tissues $(9,14)$. The generation of $\mathrm{H}_{2} \mathrm{O}_{2}$ is implicated in the progression of atherosclerosis and $\mathrm{H}_{2} \mathrm{O}_{2}$ mediates various cellular responses. Thus, $\mathrm{H}_{2} \mathrm{O}_{2}$ has been extensively used as an oxidative stimulus to induce oxidative stress in in vitro models. Falone et al (15) may have laid the foundation for the development of non-invasive pulsed electromagnetic frequency-based approaches aimed at elevating endogenous antioxidant properties in cellular or tissue models. Furthermore, Venditti et al (16) investigated substitution of the oldest ROS-overproducing mitochondria with neoformed mitochondria endowed with a smaller capacity to produce free radicals. As the major type of endothelial cells, human umbilical vein endothelial cells (HUVECs) are commonly accepted as a model cell to investigate the mechanisms involved in the pathogenesis of CVDs (17).

The present study, therefore, aimed to investigate the protective effect of the histamine $\mathrm{H} 1$ receptor antagonist, astemizole, on HUVECs. The present study investigated the action of astemizole as an anti-ROS agent in HUVECs and demonstrated that astemizole may exert its anti-ROS effect via

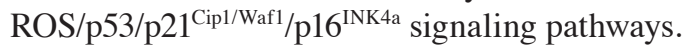

\section{Materials and methods}

Chemicals and reagents. Astemizole, $\mathrm{H}_{2} \mathrm{O}_{2}$, dimethylsulfoxide (DMSO) and MTT were obtained from Sigma-Aldrich; Merck Millipore (Darmstadt, Germany). The levels of malondialdehyde (MDA) were measured using an MDA assay kit, which is based on the thiobarbituric acid method to determine MDA in samples including blood, urine and tissue. Superoxide dismutase (SOD) was measured with a WST-1 Cell Proliferation and Cytotoxicity Assay kit, glutathione peroxidase (GSH-Px) was measured with a GSH-PX assay kit based on the colorimetric method, ROS was measured using a Reactive Oxygen Species Assay kit. All kits were purchased from Beyotime Institute of Biotechnology, Haimen, China. The following primary antibodies were obtained: Anti-p16 ${ }^{\text {INK4a }}$ (sc-377412; 1:500), anti-GAPDH (sc-32233; 1:2,000) (both from Santa Cruz Biotechnology, Inc., Dallas, TX, USA), anti-p21 ${ }^{\text {Cip1/Waf1 }}$ (610233; 1:1,000; BD Pharmingen, San Diego, CA, USA), anti-p53 (9282, 1:1,000), horse radish peroxidase (HRP)-linked anti-rabbit immunoglobulin (Ig)-G (\#7074; 1:5,000) and HRP-linked anti-mouse IgG (\#7076; 1:5,000) (both from Cell Signaling Technology, Inc., Danvers, MA, USA). All other reagents used were of analytical grade.

Cell culture and treatment. HUVECs were purchased from Shanghai Zhong Qiao Xin Zhou Biotechnology Co., Ltd (Shanghai, China). The cells were maintained in endothelial cell medium (ECM; Corning Incorporated, Corning, NY, USA) supplemented with 5\% fetal bovine serum (Zhejiang Tianhang Biotechnology Co., Ltd., Huzhou, China) and 1\% endothelial cell growth supplement in Poly- $L$-Lysine-pretreated flasks, at $37^{\circ} \mathrm{C}$ in a $5 \% \mathrm{CO}_{2}$ incubator. HUVECs were treated with astemizole $(0,0.25,0.50$ or $1.00 \mu \mathrm{M})$ for $12 \mathrm{~h}$ at $4^{\circ} \mathrm{C}$, or a PBS vehicle control. The culture supernatant was subsequently removed and the cells were exposed to $\mathrm{H}_{2} \mathrm{O}_{2}(200 \mu \mathrm{M})$ diluted in ECM for $12 \mathrm{~h}$ at $37^{\circ} \mathrm{C}$ until further assays.
Cell viability measurement. Cell morphology was assessed using a light microscope. The viability of HUVECs was measured using the MTT assay. DMSO was used as the solvent. The absorbance at $490 \mathrm{~nm}$ in each well was determined using a microplate autoreader (Bio-Rad Laboratories, Inc. Hercules, CA, USA). The viability of HUVECs in each well was presented as a percentage of the control group.

Measurement of MDA level and activities of SOD and GSH-Px. The level of MDA and the activity of SOD and GSH-Px in HUVECs were measured using MDA, SOD and GSH-Px detection kits (Beyotime Institute of Biotechnology, Haimen, China), respectively, according to the manufacturer's instructions.

Detection of ROS level. The level of intracellular ROS was determined using an ROS assay kit (Beyotime Institute of Biotechnology) according to the manufacturer's protocol. The fluorescence intensity was measured using a flow cytometer under an excitation wavelength of $488 \mathrm{~nm}$. Analyses were performed using bivariate flow cytometry in a BD FACSCanto II, equipped with BD FACSDiva (Becton-Dickinson, San Jose, CA, USA).

Western blot analysis. Total protein samples were extracted from HUVECs with radioimmunoprecipitation assay lysis buffer (Beyotime Institute of Biotechnology). Protein concentration was determined using a bicinchoninic acid protein assay kit (Beyotime Institute of Biotechnology). Protein samples $(100 \mu \mathrm{g})$ were separated by SDS-PAGE $(10 \%$ polyacrylamide gels) and transferred to a nitrocellulose membrane (EMD Millipore, Billerica, MA, USA). The membranes were subsequently blocked with milk powder at room temperature for $2 \mathrm{~h}$ and incubated overnight at $4^{\circ} \mathrm{C}$ with the primary antibody. The following day, membranes were washed and incubated with HRP-conjugated secondary anti-rabbit or anti-mouse antibody for $1 \mathrm{~h}$ at room temperature. Specific proteins were visualized using enhanced chemiluminescence (ECL) detection with BeyoECL Plus (Beyotime Institute of Biotechnology, Beijing, China). Western blot bands were quantified using Odyssey v1.2 software (LI-COR Biosciences, Lincoln, NE, USA) by measuring the band intensity (area $\mathrm{x}$ optical density) for each group and normalizing to GAPDH.

Statistical analysis. The data are presented as the mean \pm standard error of the mean or the mean \pm standard deviation. Statistical comparisons among multiple groups were performed by one-way analysis of variance followed by Tukey's multiple comparison test. $\mathrm{P}<0.05$ was considered to indicate statistical significance. Statistical values were calculated using SPSS 19.0 (IBM SPSS, Armonk, NY, USA) and illustrated using Graph Pad Prism 5.0 (GraphPad Software, Inc., La Jolla, CA, USA).

\section{Results}

Effects of astemizole on the viability of $\mathrm{H}_{2} \mathrm{O}_{2}$-induced HUVECs. Visualization of the cells by light microscopy revealed alterations to the shape and size of the HUVECs (Fig. 1A). $\mathrm{H}_{2} \mathrm{O}_{2}$ treatment caused injury to the HUVECs, however, astemizole inhibited the detrimental effect of $\mathrm{H}_{2} \mathrm{O}_{2}$ 


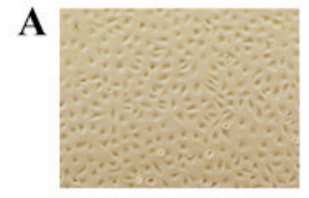

Ctrl
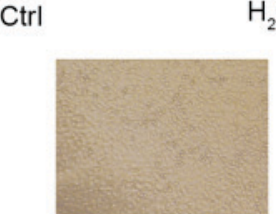

$\mathrm{H}_{2} \mathrm{O}_{2}+$

astemizole $(0.5 \mu \mathrm{M})$

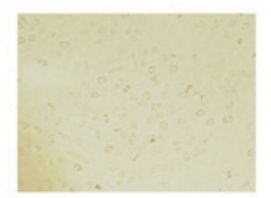

$\mathrm{H}_{2} \mathrm{O}_{2}$

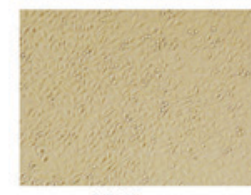

$\mathrm{H}_{2} \mathrm{O}_{2}+$

astemizole $(0.25 \mu \mathrm{M})$

B

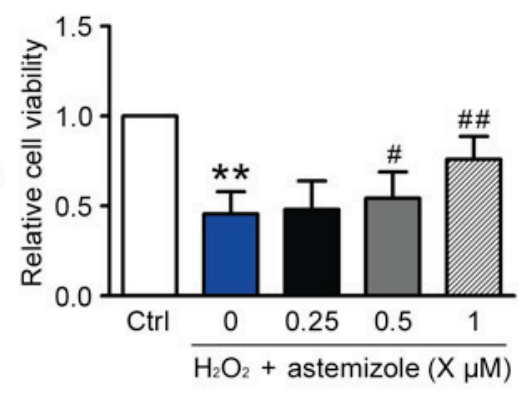

Figure 1. Effects of astemizole on $\mathrm{H}_{2} \mathrm{O}_{2}$-induced cellular injury in HUVECs. HUVECs were pretreated with $0.25,0.5$ or $1 \mu \mathrm{M}$ astemizole for $12 \mathrm{~h}$, and subsequently exposed to $\mathrm{H}_{2} \mathrm{O}_{2}(200 \mu \mathrm{M})$ for $12 \mathrm{~h}$. (A) Cell morphology and (B) relative cell viability of HUVECs from different groups. Data are presented as the mean + standard deviation. Original magnification, $\mathrm{x} 100{ }^{*}{ }^{* *} \mathrm{P}<0.01$ vs. Ctrl. ${ }^{\#} \mathrm{P}<0.05$ and ${ }^{\# \#} \mathrm{P}<0.01$ vs. $\mathrm{H}_{2} \mathrm{O}_{2}$ only-treated cells. Data were from at least 3 independent experiments, each performed in duplicate. $\mathrm{H}_{2} \mathrm{O}_{2}$, hydrogen peroxide; HUVECs, human umbilical vein endothelial cells; Ctrl, control.

and promoted the normal morphology of HUVECs. The effects of astemizole on the viability of HUVECs exposed to $\mathrm{H}_{2} \mathrm{O}_{2}$ were evaluated by MTT analysis (Fig. 1B). The survival rate of HUVECs was $48.92 \pm 3.48 \%$, as a percentage of control cell viability, following exposure to $200 \mu \mathrm{M}$ of $\mathrm{H}_{2} \mathrm{O}_{2}$ for $12 \mathrm{~h}$ $(\mathrm{P}<0.01$; Fig. 1B). Pretreatment with astemizole $(0.5$ or $1 \mu \mathrm{M})$ significantly increased the viability of HUVECs exposed to $\mathrm{H}_{2} \mathrm{O}_{2}$, in a dose-dependent manner, compared with $\mathrm{H}_{2} \mathrm{O}_{2}$ only $(\mathrm{P}<0.05$ and $\mathrm{P}<0.01$, respectively; Fig. 1B). However, pretreatment with $0.25 \mu \mathrm{M}$ astemizole for $12 \mathrm{~h}$ did not increase the cell viability compared with the $\mathrm{H}_{2} \mathrm{O}_{2}$ only group $(\mathrm{P}>0.05$; Fig. 1B). When incubated with $0.0625-2 \mu \mathrm{M}$ astemizole alone for $24 \mathrm{~h}$, cell viability did not exhibit marked changes compared with the control group, although significant cytotoxicity was observed with $4 \mu \mathrm{M}$ astemizole treatment for $24 \mathrm{~h}$ (data not shown). Therefore, only concentrations of 0.5 and $1 \mathrm{mM}$ astemizole were used throughout subsequent experiments in this study.

Astemizole inhibits oxidative stress in HUVECs. Levels of ROS and MDA were increased when cells were exposed to $\mathrm{H}_{2} \mathrm{O}_{2}(200 \mu \mathrm{M}$ for $12 \mathrm{~h})$ compared with control cells ( $\mathrm{P}<0.01$; Fig. 2A and B, respectively). However, the HUVECs co-cultured with 0.5 or $1 \mu \mathrm{M}$ astemizole exhibited significant decreases in ROS and MDA levels compared with $\mathrm{H}_{2} \mathrm{O}_{2}$ only-treated cells (Fig. 2A and B). Additionally, the activities of SOD and GSH-Px were reduced following exposure to $\mathrm{H}_{2} \mathrm{O}_{2}(200 \mu \mathrm{M}$, $12 \mathrm{~h})$ compared with the control $(\mathrm{P}<0.01$; Fig. $2 \mathrm{C}$ and $\mathrm{D})$. However, groups pretreated with $1 \mu \mathrm{M}$ astermizole prior to $\mathrm{H}_{2} \mathrm{O}_{2}$ exposure exhibited significantly increased activities of SOD and GSH-Px compared with the $\mathrm{H}_{2} \mathrm{O}_{2}$ only-treated cells (Fig. 2C and D).

Astemizole decreases expression of p53, $p 21^{\text {Cipl/Wafl }}$ and $p 16^{I N K 4 a}$ in HUVECs. To investigate the mechanisms that mediate the antioxidative effect of astemizole, the present study performed western blot analysis. The results demonstrated that $\mathrm{p} 53$, p $21^{\mathrm{Cip} 1 / \text { Waf1 }}$ and $\mathrm{p} 16^{\mathrm{INK} 4 \mathrm{a}}$ protein expression was significantly increased in HUVECs treated with $\mathrm{H}_{2} \mathrm{O}_{2}$ compared with the control group (Fig. 3). The p53 pathway is implicated in numerous diseases, including cancer (18), senescence (19) and heart failure (20). In addition, Pietrzkowicz et al (21) previously demonstrated the effects of the H1-receptor antagonists, terfenadine and astemizole, on the CV system of humans. In the present study, pretreatment with $1 \mu \mathrm{M}$ astemizole significantly decreased the expression of $\mathrm{p} 53$, $\mathrm{p} 21^{\mathrm{Cip} 1 /}$ Wafl and p16 ${ }^{\text {INK4a }}$ compared with the $\mathrm{H}_{2} \mathrm{O}_{2}$ only-treated cells $(\mathrm{P}<0.05$; Fig. 3A-C, respectively). The results indicate that changes in $\mathrm{p} 53, \mathrm{p} 21^{\mathrm{Cip} 1 / \text { Wafl }}$ and $\mathrm{p} 16^{\mathrm{INK} 4 \mathrm{a}}$ may have an important role in the ability of astemizole to protect HUVECs against $\mathrm{H}_{2} \mathrm{O}_{2}$-induced injury.

\section{Discussion}

Astemizole possesses a variety of unique properties and has also gained attention as a potential antineoplastic drug as it targets important ion channels involved in cancer progression. However, the effect of astemizole on oxidative stress in HUVECs has, to the best of our knowledge, not been investigated previously, and limited information is known about the effect of its actions. The present study demonstrated that astemizole affects HUVECs. Astemizole protected HUVECs exposed to $\mathrm{H}_{2} \mathrm{O}_{2}$ in a dose-dependent manner. Hydrogen peroxide caused significant increases in ROS, MDA, p53, $\mathrm{p} 21^{\mathrm{Cip} 1 / \mathrm{Waf} 1}$ and $\mathrm{p} 16^{\mathrm{INK} 4 \mathrm{a}}$, and decreases in the antioxidant enzymes SOD and GSH-Px, as observed in HUVECs. In addition, astemizole $(1 \mu \mathrm{M})$ significantly reversed the aberrant alterations induced by $\mathrm{H}_{2} \mathrm{O}_{2}$ in ROS levels, endogenous antioxidant activities and the protein expression of $\mathrm{p} 53$, p2 $1^{\text {Cip1/Waf1 }}$ and $\mathrm{p} 16^{\mathrm{INK} 4 \mathrm{a}}$. The results of the present study suggest that the ROS/p53/p21 1 ip1/Waf1 $/ \mathrm{p} 16^{\text {INK4a }}$ signaling cascade may be involved in CVDs. The present study demonstrates the efficacy of astemizole against oxidative stress and provides a potential novel strategy for slowing the progression of CVDs.

Oxidative stress has a major role in numerous pathological conditions (20-24) and the molecular mechanisms that control the cell response to ROS have been extensively studied. Endothelial cells are involved in several aspects of the generation and development of a number of CVDs, including hypertension and arteriosclerosis. The present study, via the use of a $\mathrm{H}_{2} \mathrm{O}_{2}$ model, has provided information about the pathogenesis of CVDs; $\mathrm{H}_{2} \mathrm{O}_{2}$-induced damage, and decreases in cellular antioxidant ability, which may result in increased apoptosis, were observed at $\mathrm{H}_{2} \mathrm{O}_{2}$ concentrations $\geqq 200 \mathrm{mM}$. 
A

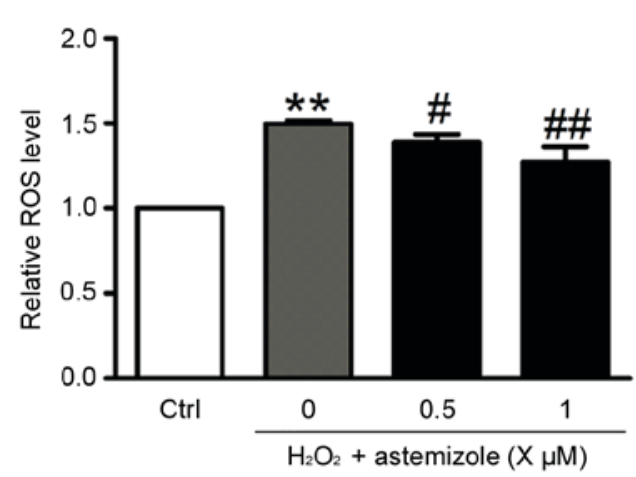

C

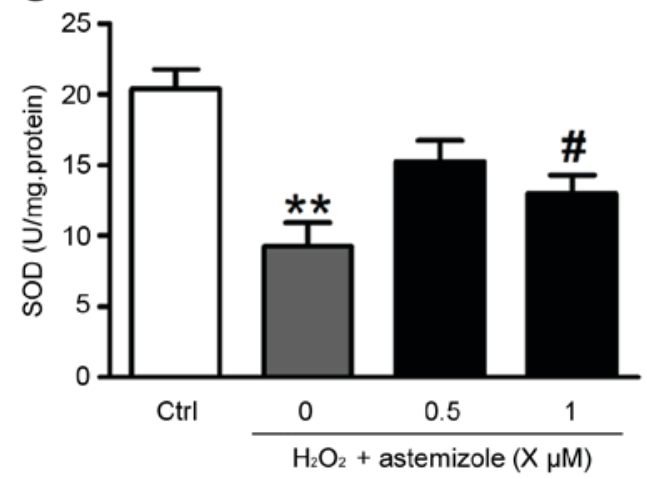

B

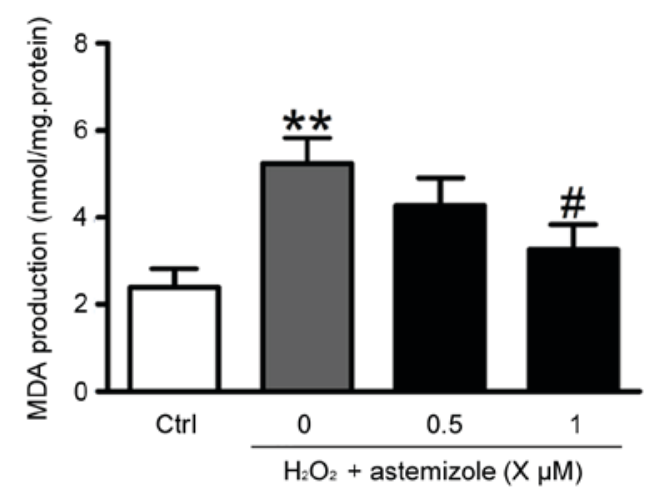

D

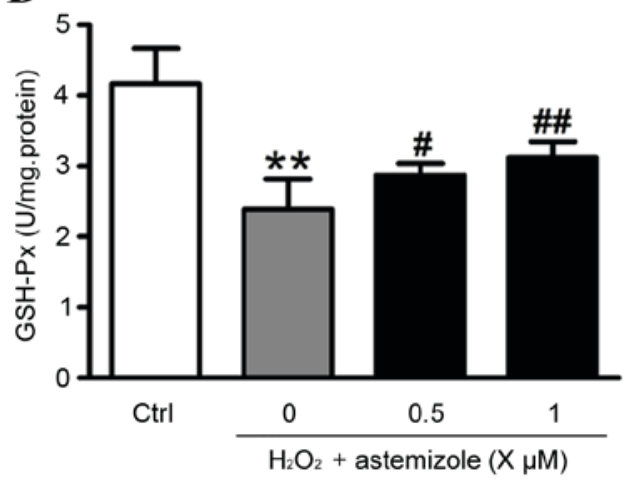

Figure 2. Astemizole improves the antioxidative capacity of human umbilical vein endothelial cells. Human umbilical vein endothelial cells were pretreated with 0.5 or $1 \mu \mathrm{M}$ astemizole for $12 \mathrm{~h}$, and subsequently exposed to $\mathrm{H}_{2} \mathrm{O}_{2}(200 \mu \mathrm{M}$ ) for $12 \mathrm{~h}$. (A) ROS levels. (B) MDA levels. (C) SOD activity. (D) GSH-Px activity. Data are presented as the mean + standard error of the mean, $\mathrm{n}=3$ per group. ${ }^{* *} \mathrm{P}<0.01$ vs. Ctrl. ${ }^{\#} \mathrm{P}<0.05$ and ${ }^{\# \#} \mathrm{P}<0.01$ vs. $\mathrm{H}_{2} \mathrm{O}_{2}$ only-treated cells. $\mathrm{ROS}$,

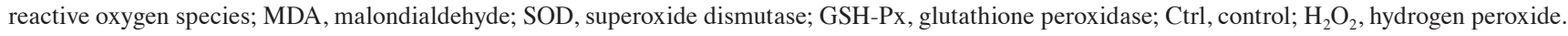

A
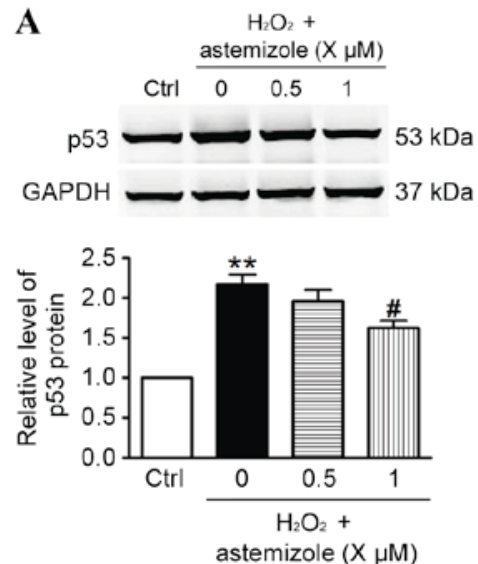

B

$\mathrm{H}_{2} \mathrm{O}_{2}+$

$\frac{\text { astemizole }(X \mu M)}{0.5}$

$\mathrm{p} 21-21 \mathrm{kDa}$
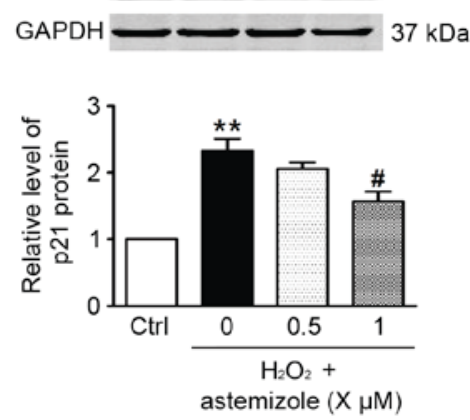

C

C $\mathrm{H}_{2} \mathrm{O}_{2}+$
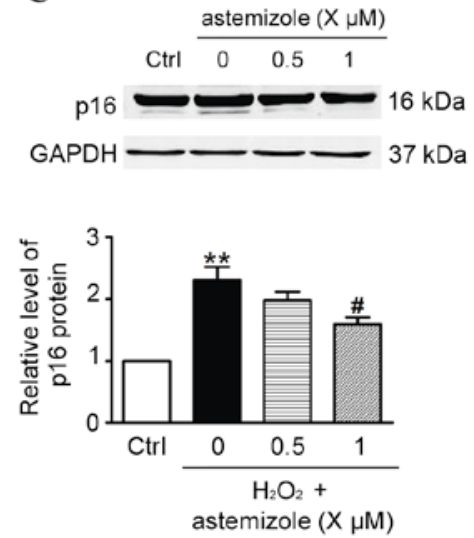

Figure 3. Astemizole reduces the protein expression of $\mathrm{p} 53$, $\mathrm{p} 21^{\mathrm{Cip} 1 / \mathrm{Waf} 1}$ and $\mathrm{p} 16^{\mathrm{INK} 4 \mathrm{a}}$ in human umbilical vein endothelial cells following $\mathrm{H}_{2} \mathrm{O}_{2}$ injury. $\mathrm{HUVECs}$ were pretreated with 0.5 or $1 \mu \mathrm{M}$ astemizole for $12 \mathrm{~h}$, and subsequently exposed to $\mathrm{H}_{2} \mathrm{O}_{2}(200 \mu \mathrm{M})$ for $12 \mathrm{~h}$. Western blot analysis was used to evaluate the protein expression levels of (A) p53, (B) p21 $1^{\text {Cipl/Waf1 }}$ and (C) $\mathrm{p} 16^{\mathrm{INK} 4 \mathrm{a}}$. Data are presented as the mean + standard error of the mean, $\mathrm{n}=3$ per group. ${ }^{* *} \mathrm{P}<0.01 \mathrm{vs}$. Ctrl. ${ }^{~} \mathrm{P}<0.05$ vs. $\mathrm{H}_{2} \mathrm{O}_{2}$ only-treated cells. HUVECs, human umbilical vein endothelial cells; $\mathrm{H}_{2} \mathrm{O}_{2}$, hydrogen peroxide; Ctrl, control.

Agents that inhibit the production of ROS or enhance cellular antioxidant defenses protect cells from the damaging effects of oxygen radicals (25). The present study demonstrated that astemizole scavenges intracellular ROS induced by $\mathrm{H}_{2} \mathrm{O}_{2}$ (Fig. 2A) and also effectively increases the viability of endothelial cells exposed to $\mathrm{H}_{2} \mathrm{O}_{2}$ (Fig. 1). These results indicate that the protective effect is associated the inhibition of the production of ROS or enhanced cellular antioxidant ability. In addition, the present study demonstrated that increases in ROS and MDA levels, and reduced activities of SOD and GSH-Px, have an important role in CVDs (19). This imbalance between enhanced oxidative stress and reduced antioxidant defense is involved in the aging process (26). The results of the current study demonstrated that pretreatment with astemizole $(1 \mu \mathrm{M})$ 
caused significant decreases in ROS, MDA and increases in antioxidant enzymes SOD and GSH-Px, compared with $\mathrm{H}_{2} \mathrm{O}_{2}$ only-treated cells.

The p53 signaling pathway has important functions in apoptosis, senescence and autophagy (19,27-29) Fibroblast growth factor-23 induces cellular senescence in human mesenchymal stem cells from skeletal muscle (30). A marine steroid derived from Acropora formosa has been demonstrated to enhance mitochondrial-mediated apoptosis in non-small cell lung cancer cells (31). The results of the present study demonstrate that astemizole may protect HUVECs that are damaged by $\mathrm{H}_{2} \mathrm{O}_{2}$, and this anti-oxidative stress effect appears to be conferred by effects on antioxidative enzymes and p53/p21 $1^{\text {Cip1/Waf1 } / p 16}{ }^{\text {INK4a }}$ signaling. The results are consistent with a study by Lee et al (32), which demonstrated that astemizole may be a novel biomarker for cardiotoxicity. The present study demonstrated that $\mathrm{p} 53$, p $21^{\mathrm{Cip} 1 / \text { Waf1 }}$ and $\mathrm{p} 16^{\mathrm{INK} 4 \mathrm{a}}$ protein expression was higher following HUVEC injury, indicating that the $\mathrm{p} 53 / \mathrm{p} 21^{\mathrm{Cip} 1 / \mathrm{Waf} 1 / \mathrm{p} 16^{\mathrm{INK} 4 \mathrm{a}}}$ signaling pathway may be involved in $\mathrm{H}_{2} \mathrm{O}_{2}$-induced HUVEC injury.

The current study demonstrated that astemizole, at low and safe concentrations, protected against $\mathrm{H}_{2} \mathrm{O}_{2}$-induced damaged that is associated with CVDs. Treatment with astemizole

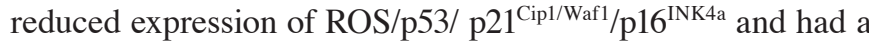
protective effect on endothelial cells. Further investigation is required to determine whether astemizole may be used as an anti-CVD agent in clinical patients.

\section{References}

1. Garcia-Quiroz J, Garcia-Becerra R, Barrera D, Santos N, Avila E, Ordaz-Rosado D, Rivas-Suárez M, Halhali A, Rodríguez P, Gamboa-Domínguez A, et al: Astemizole synergizes calcitriol antiproliferative activity by inhibiting CYP24A1 and upregulating VDR: A novel approach for breast cancer therapy. PLoS One7: e45063, 2012

2. Garcia-Quiroz J and Camacho J: Astemizole: An old anti-histamine as a new promising anti-cancer drug. Anticancer Agents Med Chem 11: 307-314, 2011.

3. Garcia-Quiroz J, Garcia-Becerra R, Santos-Martinez N, Barrera D, Ordaz-Rosado D, Avila E, Halhali A, Villanueva O, Ibarra-Sánchez MJ, Esparza-López J, et al: In vivo dual targeting of the oncogenic Ether-à-go-go-1 potassium channel by calcitriol and astemizole results in enhanced antineoplastic effects in breast tumors. BMC Cancer14: 745, 2014.

4. Sanderson JT: The steroid hormone biosynthesis pathway as a target for endocrine-disrupting chemicals. Toxicol Sci 94: 3-21, 2006.

5. Fischer MJ,Paulussen JJ,Kok-Van Esterik JA, Van der Heijden VS, De Mol NJ and Janssen LH: Effects of the anti-allergics astemizole and norastemizole on Fc epsilon RI receptor-mediated signal transduction processes. Eur J Pharmacol 322: 97-105, 1997.

6. Nishimoto M, Hashimoto H, Ohmura T, Ikeda Y, Watanabe S, Ohashi K, Umemura K and Nakashima M: Effects of astemizole on ventricular activation delay and RT intervals in a canine myocardial infarction model. Biol Pharm Bull 20: 1020-1023, 1997.

7. Romero L, Trenor B, Yang PC, Saiz J and Clancy CE: In silico screening of the impact of hERG channel kinetic abnormalities on channel block and susceptibility to acquired long QT syndrome. J Mol Cell Cardiol 87: 271-282, 2015 .

8. Cai H: Hydrogen peroxide regulation of endothelial function: Origins, mechanisms, and consequences. Cardiovasc Res 68: 26-36, 2005.

9. Liu L, Gu L, Ma Q, Zhu D and Huang X: Resveratrol attenuates hydrogen peroxide-induced apoptosis in human umbilical vein endothelial cells. Eur Rev Med Pharmacol Sci 17: 88-94, 2013.

10. Ross R: The pathogenesis of atherosclerosis: A perspective for the 1990s. Nature 362: 801-809, 1993
11. Pandian RP, Kutala VK, Liaugminas A, Parinandi NL and Kuppusamy P: Lipopolysaccharide-induced alterations in oxygen consumption and radical generation in endothelial cells. Mol Cell Biochem 278: 119-127, 2005.

12. Fasanaro P, Magenta A, Zaccagnini G, Cicchillitti L, Fucile S, Eusebi F, Biglioli P, Capogrossi MC and Martelli F: Cyclin D1 degradation enhances endothelial cell survival upon oxidative stress. FASEB J 20: 1242-1244, 2006.

13. Xu HB and Huang ZQ: Icariin enhances endothelial nitric-oxide synthase expression on human endothelial cells in vitro. Vascul Pharmacol 47: 18-24, 2007.

14. Kamata $\mathrm{H}$ and Hirata $\mathrm{H}$ : Redox regulation of cellular signalling. Cell Signal 11: 1-14, 1999.

15. Falone S, Marchesi N, Osera C, Fassina L, Comincini S, Amadio $\mathrm{M}$ and Pascale A: Pulsed electromagnetic field (PEMF) prevents pro-oxidant effects of $\mathrm{H} 2 \mathrm{O} 2$ in SK-N-BE(2) human neuroblastoma cells. Int J Radiat Biol 92: 281-286, 2016.

16. Venditti P, Costagliola IR and Di Meo S: H2O2 production and response to stress conditions by mitochondrial fractions from rat liver. J Bioenerg Biomembr 34: 115-125, 2002.

17. Xia Z, Liu M, Wu Y, Sharma V, Luo T, Ouyang J and McNeill JH: $\mathrm{N}$-acetylcysteine attenuates TNF-alpha-induced human vascular endothelial cell apoptosis and restores eNOS expression. Eur J Pharmacol 550: 134-142, 2006

18. Ormenisan C, Kubik M, Legrand S, Kraemer D, Smotherman C and Masood S: The potential of ki67 and p53 assessment in development of individualized targeted therapy in breast cancer patients. Pathologica 107: 177-180, 2015.

19. Zhang M, Liu D, Li S, Chang L, Zhang Y, Liu R, Sun F, Duan W, Du W, Wu Y, et al: Bone marrow mesenchymal stem cell transplantation retards the natural senescence of rat hearts. Stem Cells Transl Med 4: 494-502, 2015.

20. Oka T, Morita H and Komuro I: Novel molecular mechanisms and regeneration therapy for heart failure. J Mol Cell Cardiol 92: 46-51,2016.

21. Pietrzkowicz M and Grzelewska-Rzymowska I: The effect of new H1-receptor antagonists on cardiovascular system. Pol Merkur Lekarski 5: 360-362, 1998 (In Polish).

22. Griendling KK and FitzGerald GA: Oxidative stress and cardiovascular injury: Part II: Animal and human studies. Circulation 108: 2034-2040, 2003.

23. Griendling KK and FitzGerald GA: Oxidative stress and cardiovascular injury: Part I: Basic mechanisms and in vivo monitoring of ROS. Circulation108: 1912-1916, 2003.

24. Giustarini D, Dalle-Donne I, Tsikas D and Rossi R: Oxidative stress and human diseases: Origin, link, measurement, mechanisms, and biomarkers. Crit Rev Clin Lab Sci 46: 241-281, 2009.

25. Wang YK and Huang ZQ: Protective effects of icariin on human umbilical vein endothelial cell injury induced by $\mathrm{H}_{2} \mathrm{O}_{2}$ in vitro. Pharmacol Res 52: 174-182, 2005.

26. Ray PD, Huang BW and Tsuji Y: Reactive oxygen species (ROS) homeostasis and redox regulation in cellular signaling. Cell Signal 24: 981-990, 2012.

27. Tseng CY, Wang JS, Chang YJ, Chang JF and Chao MW: Exposure to high-dose diesel exhaust particles induces intracellular oxidative stress and causes endothelial apoptosis in cultured in vitro capillary tube cells. Cardiovasc Toxicol 15: 345-354, 2015.

28. Xu LL, Liu ML, Wang JL, Yu M and Chen JX: Saligenin cyclic-o-tolyl phosphate (SCOTP) induces autophagy of rat spermatogonial stem cells. Reprod Toxicol 60: 62-68, 2016.

29. Song YM, Lee WK, Lee YH, Kang ES, Cha BS and Lee BW: Metformin restores parkin-mediated mitophagy, suppressed by cytosolic p53. Int J Mol Sci 17: pii: E122, 2016.

30. Sato C, Iso Y, Mizukami T, Otabe K, Sasai M, Kurata M, Sanbe T, Sekiya I, Miyazaki A and Suzuki H: Fibroblast growth factor-23 induces cellular senescence in human mesenchymal stem cells from skeletal muscle. Biochem Biophys Res Commun 470: 657-662, 2016.

31. Vaikundamoorthy R, Sundaramoorthy R, Krishnamoorthy V, Vilwanathan R and Rajendran R: Marine steroid derived from Acropora formosa enhances mitochondrial-mediated apoptosis in non-small cell lung cancer cells. Tumour Biol 37: 10517-10531, 2016.

32. Lee EH, Oh JH, Park HJ, Kim DG, Lee JH, Kim CY, Kwon MS and Yoon S: Simultaneous gene expression signature of heart and peripheral blood mononuclear cells in astemizole-treated rats. Arch Toxicol 84: 609-618, 2010. 